\title{
Aggressive Non-Hodgkin Lymphoma
}

National Cancer Institute

\section{Source}

National Cancer Institute. Aggressive Non-Hodgkin Lymphoma. NCI Thesaurus. Code C9244.

A non-Hodgkin lymphoma with an aggressive clinical course. Representative examples include Burkitt lymphoma, mantle cell lymphoma, and ang ioimmunoblastic T-cell lymphoma. 